\title{
Investigation in the Use of Low Sulphide Coal Tailings in Covers with Capillary Barrier Effects to Prevent Acid Mine Drainage
}

\author{
N. van Wyk, E. Fosso-Kankeu*, F.B. Waanders, M. Le Roux and Q.P. Campbell
}

\begin{abstract}
Acid mine drainage generated by mining industries has a variety of diverse effects on the environment and human health. Assessing the acid generating capability of mine waste is extremely important in developing a remediation strategy. Acid-base accounting (ABA) and net acid generation (NAG) tests are the most commonly used test in the evaluation of acid generation capabilities of mine waste.

Covers with capillary barrier effects (CCBE) are one of the most effective techniques used to control AMD. The use of low sulphide mine waste to construct a CCBC cover would allow for the construction of a highly effective AMD prevention technique and ensure a safe disposal of mine waste.
\end{abstract}

Keywords - Acid Base Accounting (ABA), Net Acid generation, Acid generation potential, Coal mine tailings, Middleburg.

\section{INTRODUCTION}

Large quantities of ore are excavated during mining activities. The excavated ore is subject to a benefaction process, which discards the low-grade material which cannot be processed economically. The low-grade material is commonly deposited into the environment in large piles (tailings). The tailings can reach up to a hundred meter high and stretch for kilometers. These tailings commonly contain elements in lower concentrations, however most tailing deposits still contain elevated concentration of acid generating sulphide minerals [1-5].

Acid mine drainage (AMD) is a result of acid that is generated by oxidation of sulphide minerals within the tailings. Sulphide minerals react with oxygen and water supplied by the environment to produce acid. Pyrite $\left(\mathrm{FeS}_{2}\right)$ and pyrrhotite $\left(\mathrm{Fe}_{\mathrm{x}} \mathrm{S}\right)$ are the most common acid generating sulphide minerals

E. Fosso-Kankeu is with the Water Pollution Monitoring and Remediation Initiatives Research Group, School of Chemical and Minerals Engineering, North-West University, Potchefstroom, South Africa.

N. van Wyk is with the Water Pollution Monitoring and Remediation Initiatives Research Group, School of Chemical and Minerals Engineering, North-West University, Potchefstroom, South Africa.

F.B. Waanders is with the Water Pollution Monitoring and Remediation Initiatives Research Group, School of Chemical and Minerals Engineering, North-West University, Potchefstroom, South Africa.

Q.P. Campbell is with the Coal Beneficiation Research Group in the School of Chemical and Minerals Engineering of the North West University, Potchefstroom-South Africa.

M. Le Roux is with the Coal Beneficiation Research Group in the School of Chemical and Minerals Engineering of the North West University, Potchefstroom-South Africa. found in waste rock tailings and are considered to contribute the most to acid generation $[1,6,7]$.

The AMD effluent is usually highly acidic and commonly contains high concentration of sulphates $\left(\mathrm{SO}_{4}{ }^{2-}\right)$ and dissolved metals such as iron, lead, nickel, aluminium, manganese, copper, zinc and cadmium. The metal release is promoted by the acid generated during the oxidation of sulphide minerals $[2$, 7-9].

The acid is generated from oxidation reactions of pyrite and pyrrhotite in the presence of oxygen as shown in (1) and (2) respectively. The acid can be generated from oxidation reaction of pyrite and pyrrhotite via ferric iron at a $\mathrm{pH}$ below 4 as expressed in (3) and (4) respectively [10].

$$
\begin{gathered}
\mathrm{FeS}_{2}+3.75 \mathrm{O}_{2}+3.5 \mathrm{H}_{2} \mathrm{O}=\mathrm{Fe}(\mathrm{OH})_{3}+2 \mathrm{SO}_{4}{ }^{2-}+4 \mathrm{H}^{+} \\
\mathrm{Fe}_{0.9} \mathrm{~S}+2.175 \mathrm{O}_{2}+2.35 \mathrm{H}_{2} \mathrm{O}=0.9 \mathrm{Fe}(\mathrm{OH})_{3}+\mathrm{SO}_{4}{ }^{2-}+2 \mathrm{H}^{+} \\
\mathrm{FeS}_{2}+14 \mathrm{Fe}^{3+}+8 \mathrm{H}_{2} \mathrm{O}=15 \mathrm{Fe}^{2+}+2 \mathrm{SO}_{4}{ }^{2-}+16 \mathrm{H}^{+} \\
\mathrm{Fe}_{0.9} \mathrm{~S}+7.8 \mathrm{Fe}^{3+}+4 \mathrm{H}_{2} \mathrm{O}=8.7 \mathrm{Fe}^{2+}+\mathrm{SO}_{4}{ }^{2-}+8 \mathrm{H}^{+}
\end{gathered}
$$

As seen when comparing (1) to (3), the amount of acid is generated increases four times when pyrite is oxidized by ferric iron compared to oxygen. The same happens when pyrrhotite is oxidized by ferric iron as seen when comparing (2) and (4). The rate of acid generation is increased as well [10]. Non-acid generating sulphide minerals become acid generating minerals when oxidized by ferric iron. This can be seen in (5) and (6) where covellite $(\mathrm{CuS})$ is oxidized by oxygen and ferric iron respectively [10].

$$
\begin{gathered}
\mathrm{CuS}+2 \mathrm{O}_{2}=\mathrm{Cu}^{2+}+\mathrm{SO}_{4}{ }^{2-} \\
\mathrm{CuS}+8 \mathrm{Fe}^{3+}+4 \mathrm{H}_{2} \mathrm{O}=\mathrm{Cu}^{2+}+8 \mathrm{Fe}^{2+}+\mathrm{SO}_{4}{ }^{2-}+8 \mathrm{H}^{+}
\end{gathered}
$$

It is thus extremely important to maintain the $\mathrm{pH}$ of mine waste above a $\mathrm{pH}$ of 4 .

Acid-base accounting (ABA) and net acid generation (NAG) tests are the most commonly used test in the evaluation of acid generation capabilities of mine waste [7].

The ABA method evaluates the physical $\mathrm{pH}$, acid-neutralizing capabilities (ANC) and the maximum potential acidity (MPA) of waste rock sample [6-8]. The net acid generation (NAG) test assesses the quantity of acid that would be generated instead of assessing the acid neutralizing and acid generation capabilities separately as done in the ABA 
method $[6,11,12]$.

Assessing the acid generating capability of mine waste is extremely important in developing an effective remediation strategy. There exists many AMD treatment and prevention techniques that may be applied to acid generating waste rock or tailings. Many of these techniques have their own advantages and disadvantages. Disadvantages associated with using traditional/conventional materials in implementing of such treatment and prevention techniques are high cost, design inaccuracies, poor performance, depletion of natural resources and the generation of additional waste. There is a need to conduct more research in the use of industrial waste or by-products in AMD treatment and prevention techniques, to develop more environmentally sustainable AMD remediation strategies [13].

Covers with capillary barrier effects (CCBE) are one of the most effective techniques used to control AMD. CCBE covers are in many cases the only applicable alternative to control AMD formation, even though the construction of a CCBE cover has a relatively high cost $[13,14]$.

The primary role of a CCBE is to limit the diffusion of oxygen to the underlying acid-generating material, thus reducing acid generation. Tolimit the diffusion of oxygen, the cover must retain as much humidity as possible in one or more of its soil layers. The saturated soil can lower the diffusion of gas to such an extent that it effectively limits the influx of oxygen from the atmosphere to the acid-generating waste material beneath $[13,14]$.

The ability of CCBE covers to maintain high degree of saturation depends on the capillary barrier effect. The capillary barrier effect is present when fine-grainer material is placed over a coarse material. The two materials have different particle size distributions resulting in different hydrogeological properties. The fine-grained material layer will retain water easier as it has smaller interstitial pores and capillary forces allow for a higher water retaining capacity. The coarse material drains during desaturation, the interconnectivity of water filled voids are reduced by the presence of gas in the coarse material pore space, which in turn reduces its hydraulic conductivity. The vertical flow of water between the fin grained material layer to the coarse material layer is decreased by the low hydraulic conductivity of the coarse material. The fine-grained material layer remains almost fully saturated resulting in a reduced oxygen flux [13].

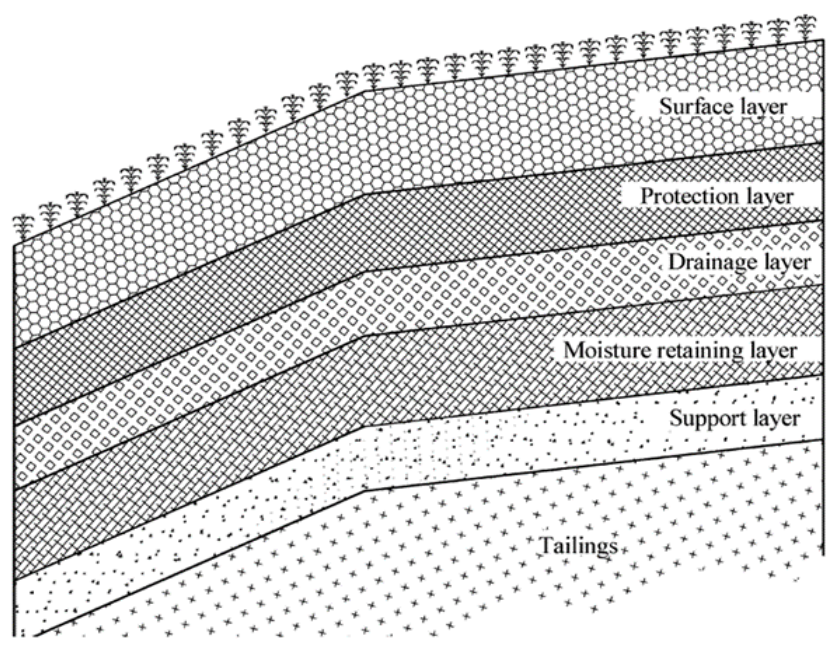

Fig. 1. CCBE configuration [13]

A CCBE usually consist of three to five layers made of different material. Each layer has its own purpose. Fig. 1. illustrates the typical configuration of a CCBE. The first layer (bottom support layer) placed above the acid-generating tailings is made of a coarse-grained material which acts as a capillary break and as a mechanical support. The second layer which is the moisture retaining layer consists of a fine-grained material. This layer used as the moisture-retaining layer and is placed above the first layer to create the capillary barrier effect. The third layer (drainage layer) consists of another coarse-grained material which helps with lateral draining and prevents the loss of water through evaporation from the moisture retaining layer. The protection layer and the surface layer are used to protect the core of the CCBE from bio-intrusion and erosion [13].

In a leach column study conducted by [10], the moisture-retaining layer of the CCBE consisted of slightly reactive low sulphide tailings. The results of the study concluded that the use of the low sulphide tailings effectively limited the acid generation and release of sulphates and heavy metals from the acid generating tailings underneath. The study further showed that the low sulphide tailings can improve the CCBE ability to limit gas diffusion by consuming a portion of the migrating oxygen.

ABA test can be conducted in relatively short time period and is relatively inexpensive analytical procedure to assess the chemical and physical properties of mine tailings. The ABA method evaluates the physical $\mathrm{pH}$ of the waste rock using past $\mathrm{pH}$ test, ability of tailings to neutralize acid using the acid neutralizing capacity (ANC) test and lastly the acid generating potential using the maximum potential acidity (MPA) test $[6,7$, 9].

The past $\mathrm{pH}$ procedure entails mixing a tailing sample with deionized water with a 2:1 (soil: water) ratio. The sample is stirred up until a thin paste is formed, after which the $\mathrm{pH}$ is measured [6, 7, 11]. Past $\mathrm{pH}$ is relatively simple and inexpensive test method to assess the readily available alkalinity/acidity of a sample. Due to the short time duration of the past $\mathrm{pH}$ test, only reactive minerals and soluble salts are assessed [11, 12]. 
Sample with a paste $\mathrm{pH}$ less than 4 provide a preliminary indicates the sample may be a potential acid forming sample, containing a large amount of acid generating sulphates, which will produce acid immediately upon being exposed to water, up to $30 \mathrm{~kg} \mathrm{H}_{2} \mathrm{SO}_{4} / \mathrm{t}$ of stored acidity. Paste $\mathrm{pH}$ between 4 and 5 are classified as potential acid forming with low stored acidity up to $9 \mathrm{~kg} \mathrm{H}_{2} \mathrm{SO}_{4} / \mathrm{t}$. Samples with a paste $\mathrm{pH}$ higher than 7 indicates a higher neutralizing capacity due to the presence of reactive carbonates. However, it may still generate AMD if the acid neutralizing components are depleted before acid generating sulphides [11, 12].

The ANC of a tailing sample refers to the ability of the tailing sample to neutralize a certain quantity of acid before it becomes acidic. The ANC test involves the digestion of a waste rock sample in acid, heating it and then titrating it to a $\mathrm{pH}$ of 7 [6,7]. [11] surges adding hydrogen peroxide at a $\mathrm{pH}$ of 5 during the titration to promote the oxidation of dissolved ferrous iron and hydrolysis of ferric iron.

The maximum potential acidity (MPA) is determined by multiplying the total sulphur or sulphide content with a factor of 30.6. The MPA is calculated based on the assumption that the total sulphur or sulphide content in a sample occurs predominantly as pyrite. Determining the MPA bases on total sulphur content may overestimate the true MPA if a large portion of sulphur forms part of sulphur bearing minerals such as barite, galena and gypsum which are non-acid forming minerals. Adjustments can be made to the MPA if the sulphide speciation is known [7,15]. The dimensions of ANC and MPA are kilograms sulphuric acid per ton of material $\left(\mathrm{kg} \mathrm{H}_{2} \mathrm{SO}_{4} / \mathrm{t}\right)$

The net acid production potential (NAPP) and ANC to MPA ratio $\left(\mathrm{R}_{\mathrm{AMD}}\right)$ are the two parameters used to evaluate the acid generating potential of a tailing sample. NAPP and ANC to MPA ratio are calculated using (7) and (8) respectively.

$$
\begin{aligned}
& N A P P=M P A-A N C \\
& R_{A M D}=A N C / M A P
\end{aligned}
$$

The NAPP and $\mathrm{R}_{\mathrm{AMD}}$ are used to classify the acid generating capabilities of tailing samples as potential acid forming (PAF), non-acid forming (NAF) or as uncertain (UN) (Table I) $[6,15]$.

TABLE I: ABA CLASSIFICATION CRITERIA

\begin{tabular}{ccc}
\hline \hline $\mathrm{R}_{\mathrm{AMD}}$ & $\begin{array}{c}\mathrm{NAPP} \\
\left(\mathrm{kg} \mathrm{H}_{2} \mathrm{SO}_{4} / \mathrm{t}\right)\end{array}$ & Classification \\
\hline$<1$ & $<-20$ & $\mathrm{PAF}$ \\
$1-2$ & $-20<N A P P>20$ & $\mathrm{UC}$ \\
$>2$ & $>20$ & $\mathrm{NAF}$ \\
\hline \hline
\end{tabular}

The ANC test is conducted using a high concentration of acid and heated at a high temperature to ensure the $\mathrm{HCl}$ acid reacts to completion with the acid neutralizing minerals within the tailing [7, 11]. However, these highly acidic and high temperature conditions may enable acid neutralizing minerals to reach that would not contribute to acid neutralization under normal environmental conditions, thus overestimating the true ANC of the tailing [17].
The acid buffering characteristic curve (ABCC) test evaluates the portion of the ANC (determined using ABA method) that are readily available to neutralize acid $[7,11]$.

Fig. 2 represents a plotted ABCC. As seen in Fig. 2, if one sample contains mostly calcite and the other ankerite, they have the same ANC value of $40 \mathrm{~kg} \mathrm{H}_{2} \mathrm{SO}_{4} / \mathrm{t}$. However, these samples have different reactivity's. The $\mathrm{pH}$ of the sample containing calcite is maintained above a $\mathrm{pH}$ of 4 until the equivalent of $42 \mathrm{~kg} \mathrm{H}_{2} \mathrm{SO}_{4} / \mathrm{t}$ has been neutralized, indicating that $100 \%$ of the ANC determined using ABA method, is readily available to neutralize acid. The $\mathrm{pH}$ of the ankerite sample drops below a pH of 4 after the equivalent of $20 \mathrm{~kg}$ $\mathrm{H}_{2} \mathrm{SO}_{4} / \mathrm{t}$ has been neutralized, indicating that only $50 \%$ of the measured ANC will be readily available to neutralize acid [7].

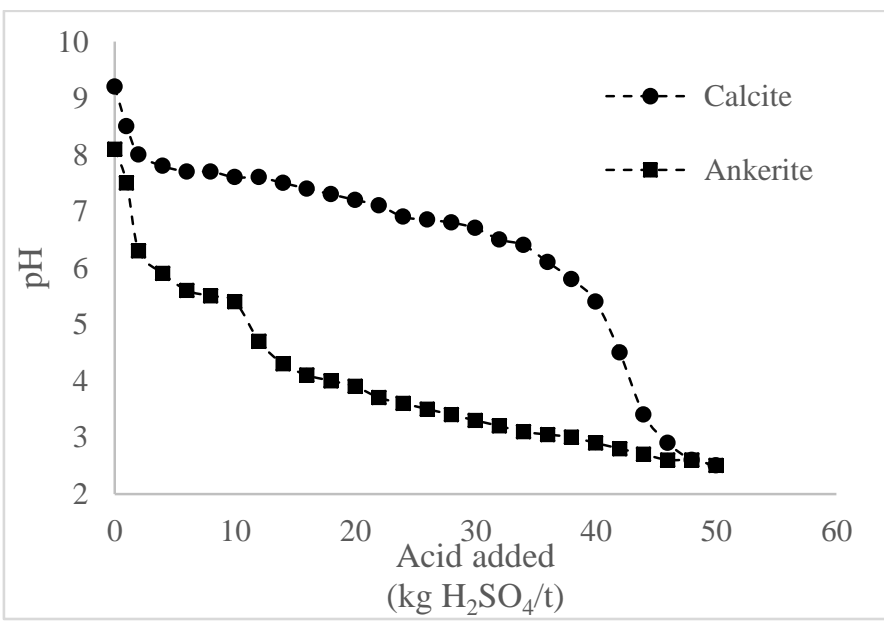

Fig. 2. ABCC plot of a calcite and ankerite sample.

The NAG test eliminates some of the uncertainties encountered in the ABA method. The NAG involves digesting a waste rock sample in hydrogen peroxide, allowing the acid generating and acid neutralizing reactions to occur simultaneously. The solution is left to react overnight and then heated the next day to encourage oxidation of remaining sulphide minerals, release of inherent neutralizing capabilities and to remove excess hydrogen peroxide. The $\mathrm{pH}$ of the solution is then measured after it had time to cool down to room temperature and is referred to as the NAGpH. The solution is then titrated to a $\mathrm{pH}$ of 4.5 and 7 using sodium hydroxide $(\mathrm{NaOH})$. The volume $\left(\mathrm{V}_{\mathrm{NaOH}}\right)$ and concentration $\left(\mathrm{M}_{\mathrm{NaOH}}\right)$ of the sodium hydroxide used during the titration is used to calculate the NAG value and is reported in $\mathrm{kg} \mathrm{H}_{2} \mathrm{SO}_{4} / \mathrm{t}(9)$ [7, 11, 12].

$$
N A G=\left(49 \times V_{\mathrm{NaOH}} \times M_{\mathrm{NaOH}}\right) / w
$$

The classification using NAG results are summarized in Table II [7, 18]. 
TABLE II: NAG CLASSIFICATION CRITERIA

\begin{tabular}{ccc}
\hline \hline NAGpH & $\begin{array}{c}\mathrm{NAG} \\
\left(\mathrm{kg} \mathrm{H}_{2} \mathrm{SO}_{4} / \mathrm{t}\right)\end{array}$ & Classification \\
\hline$>4.5$ & 0 & $\mathrm{NAF}$ \\
$\leq 4.5$ & $\leq 5$ & PAF (low capacity) \\
$\leq 4.5$ & $>5$ & PAF \\
\hline \hline
\end{tabular}

The NAPP obtained from the ABA method and NAGpH obtained from the NAG method are most commonly used together to classify the acid generating capabilities of waste rock samples as PAF, NAF or UC. Using the NAPP and $\mathrm{NAGpH}$ allows classification to a higher degree confidence. NAPP and NAGpH classification criteria are summarized in TableIII $[7,17,18]$.

TABLE III: CLASSIFICATION CRITERIA USING NAG RESULTS IN CONJUNCTION WITH ABA RESULTS

\begin{tabular}{cc}
\hline \hline Criteria & Classification \\
\hline$N A P P \leq 0, N A G p H \geq 4.5$ & NAF \\
$N A P P>0, N A G p H<4.5$ & PAF \\
$N A P P \leq 0, N A G p H<4.5$ & \\
$N A P P>0, N A G p H \geq 4.5$ & $\mathrm{UC}$ \\
\hline \hline
\end{tabular}

\section{Methodology}

\section{A. Sample collection and preparation.}

Four coal waste rock tailings samples (CS1, CS2, CS3 and CS4) were collected from a washing plant located in the Middelburg area, South Africa.

The samples were dried, milled and sieved to obtain a particle size smaller than $75 \mu \mathrm{m}$ in accordance with [7].

\section{B. Acid Base Accounting (ABA)}

\section{i. $\quad$ Paste $\mathrm{pH}$.}

A paste like slurry was prepared by adding $50 \mathrm{~mL}$ of deionized water to $25 \mathrm{~g}$ sample. The $\mathrm{pH}$ of the slurry was measured after a period of 2 hours.

\section{ii. Maximum Potential Acidity (MPA).}

The MPA was calculated by multiplying the total sulphide content with a factor of 30.6 (10).

$$
M P A=\left(\text { Total } S_{i} \%\right) \times 30.6
$$

Total sulphur (S\%) and sulphide $\left(\mathrm{S}_{\mathrm{i}} \%\right)$ were determined using an ELTRA CS 2000 Carbon Sulfur Determinator, PC controlled.

\section{iii. Acid Neutralization Capacity (ANC)}

The following ANC procedure was conducted as stipulated in $[7,11]$.

$20 \mathrm{~mL}\left(\mathrm{~V}_{\mathrm{HCl}}\right)$ of $0.5 \mathrm{M}\left(\mathrm{C}_{\mathrm{HCI}}\right)$ hydrochloric acid $(\mathrm{HCl})$ and 20 $\mathrm{mL}$ deionized water was added to each $2 \mathrm{~g}(\mathrm{~m})$ sample and mixed in a $250 \mathrm{~mL}$ flask.

The flask was covered with a watch glass and heated, maintaining the temperature between a range of $80-90^{\circ} \mathrm{C}$ for a period of 2 hours.

After heating, deionized water was added to the solution to obtain a solution volume of $125 \mathrm{~mL}$ and then allowed to further cool down to room temperature.

The $\mathrm{pH}$ of the solution was then measured after the solution had cooled down to room temperature. The solution $\mathrm{pH}$ should be between 0.8 and 1.5 to ensure complete digestion of acid neutralizing minerals.

The solution was then back titrated using $0.5 \mathrm{M}$ sodium hydroxide $(\mathrm{NaOH})$ to a $\mathrm{pH}$ of 5 . Two drops of $30 \%$ hydrogen peroxide was then added to the solution. The titration was then continued to a $\mathrm{pH}$ of 7 and 8.3. The volume of $\mathrm{NaOH}$ used during the titration $\left(\mathrm{V}_{\mathrm{NaOH}}\right)$ was recorded.

Eq. (11) was used to calculate the ANC of each sample.

$$
\mathrm{ANC}=\frac{\left(\mathrm{V}_{\mathrm{HCl}}-\left\lceil\mathrm{V}_{\mathrm{NaOH}} \times \frac{\mathrm{V}_{\mathrm{HCl}, \text { Blank }}}{\mathrm{V}_{\mathrm{NaOH}, \text { Blank }}}\right\rceil\right) \times \mathrm{C}_{\mathrm{HCl}}}{\mathrm{m}} \times 49
$$

\section{iv. $\quad$ Net acid generation $(N A G)$ test}

The following procedure was conducted in accordance with the method stipulated in $[7,11,12]$.

$2.5 \mathrm{~g}(\mathrm{~m})$ of sample was accurately weighed into a $500 \mathrm{~mL}$ flask. $250 \mathrm{~mL}$ of $15 \%$ hydrogen peroxide was then added to each sample. The solution was allowed to react overnight. The solution was then heated slightly and mixed for an hour using a magnetic stirrer. The solution was then allowed to cool down to room temperature. The $\mathrm{pH}$ of the solution was measured and recorded after the solution had cooled down and is referred to as the $\mathrm{NAGpH}$.

The solution was then titrated to a $\mathrm{pH}$ of 4.5 and 7 using 0.1 $\mathrm{M}\left[\mathrm{M}_{\mathrm{NaOH}}\right] \mathrm{NaOH}$. The volume of $\mathrm{NaOH}\left(\mathrm{V}_{\mathrm{NaOH}}\right)$ used during the titration was recorded and used to calculate the NAG value using (12).

$$
N A G=\left(49 \times V_{\mathrm{NaOH}} \times M_{\mathrm{NaOH}}\right) / m
$$

\section{v. Acid Buffering Characteristic Curve (ABCC)}

ABCC test was conducted in accordance with the test procedure described in $[7,12]$.

A solution was prepared by mixing a $2.5 \mathrm{~g}$ sample with deionized water using a magnetic stirrer. The $\mathrm{pH}$ of the solution was then measured and recorded. $0.2 \mathrm{~mL}$ of $0.5 \mathrm{M}$ $\left(\mathrm{C}_{\mathrm{HCl}}\right) \mathrm{HCl}$ was incrementally added to the sample solution. After each incremental addition, 17 min were allowed to pass after which the $\mathrm{pH}$ was then measured and recorded. The incremental addition was continued until the $\mathrm{pH}$ of the solution reached a $\mathrm{pH}$ of 2.5 .

The concentration and volume of $\mathrm{HCl}\left(\mathrm{V}_{\mathrm{HCl}}\right)$ used during the experiment was then used to construct an $\mathrm{ABCC}$ plot using 
(13).

$$
\mathrm{H}_{2} \mathrm{SO}_{4} \text { added }(\mathrm{kg} / \mathrm{t})=\left(V_{\mathrm{HCl}} \times \mathrm{C}_{\mathrm{HCl}} \times 49\right) / \mathrm{m}
$$

\section{RESULTS AND DISCUSSION}

\section{A. Acid-Base Accounting (ABA) results}

Table IV summarizes the results of the ABA method. As seen in Table IV, CS1, CS2 and CS3 have NAPP > $20 \mathrm{~kg}$ $\mathrm{H}_{2} \mathrm{SO}_{4} / \mathrm{t}$ and $\mathrm{R}_{\mathrm{AMD}}<1$ and are thus classified as PAF samples according the classification criteria summarized in Table I [6, 16]. The same criteria were used to classify CS4 as NAF as it has a NAPP $<-20 \mathrm{~kg} \mathrm{H}_{2} \mathrm{SO}_{4} / \mathrm{t}$ and an $\mathrm{R}_{\mathrm{AMD}}>2$.

\begin{tabular}{|c|c|c|c|c|c|c|c|}
\hline & $\begin{array}{c}\text { Paste } \\
\text { pH }\end{array}$ & $\mathbf{S} \%$ & $\mathrm{~S}_{\mathrm{i}} \%$ & $\begin{array}{c}\mathrm{MPA} \\
\mathbf{k g} \\
\mathrm{H}_{2} \mathrm{SO}_{4} / \mathrm{t}\end{array}$ & $\begin{array}{c}\mathbf{A N C} \\
\mathbf{k g} \\
\mathbf{H}_{2} \mathrm{SO}_{4} / \mathbf{t}\end{array}$ & $\begin{array}{c}\mathrm{NAPP} \\
\mathbf{k g} \\
\mathrm{H}_{2} \mathrm{SO}_{4} / \mathrm{t}\end{array}$ & $\mathbf{R}_{\mathrm{AMD}}$ \\
\hline CS1 & 2.1 & 2.1 & 1.6 & 50 & 0 & 50 & 0 \\
\hline CS2 & 2.3 & 4.2 & 1.6 & 48 & 0 & 48 & 0 \\
\hline CS3 & 6.8 & 2.1 & 2.1 & 63 & 30 & 33 & 0.5 \\
\hline CS4 & 7.8 & 1.1 & 1.1 & 34 & 80 & -46 & 2.3 \\
\hline
\end{tabular}

The paste $\mathrm{pH}$ of CS1 and CS2 are extremely low and indicate the tailing from which CS1 and CS2 were collected have become acidic. The extremely low paste $\mathrm{pH}$ of CS1 and CS2 confirm that CS1 and CS2 have no acid neutralizing capabilities (ANC) as seen in Table IV. This means that CS1 and CS2 have completely consumed their acid neutralizing minerals. The sulphide content of CS1 and CS2 are relatively high suggesting that acid generation will continue until all of the acid generating sulphide minerals have reacted. The low $\mathrm{pH}$ of CS1 and CS2 means that sulphide minerals will be oxidized via ferric iron resulting in the generation of larger quantities of acid at an accelerated rate as previously mentioned. This means that the NAPP of CS1 and CS2 may be substantially higher.

$\mathrm{SC} 3$ is classified as PAF as it has a NAPP $>20 \mathrm{~kg} \mathrm{H}_{2} \mathrm{SO}_{4} / \mathrm{t}$ and a $\mathrm{R}_{\mathrm{AMD}}<1$. SC3 still has a high paste $\mathrm{pH}$ and due to its acid neutralizing capabilities. As seen in Table IV, the MPA is larger than its ANC, which means its acid neutralizing minerals will be depleted before its acid generating minerals. However, this is based on the assumption the total sulphide content occurs predominantly from acid generating sulphide minerals.

CS4 is the only sample classified as NAF due to its high ANC resulting in a negative NAPP $<-20 \mathrm{~kg} \mathrm{H}_{2} \mathrm{SO}_{4} / \mathrm{t}$ and $\mathrm{R}_{\mathrm{AMD}}$ $>2$. The relatively low sulphide content and the high ANC makes CS4 a good candidate to be used as the moister-retaining layer of a CCBE.

\section{B. Acid Buffering Characteristic Curve (ABCC) results}

The ABCC plot of CS3 and CS4 are represented in Fig.3. As seen in Fig. 3, CS3 maintains a pH above 2.5 after the equivalent of $30 \mathrm{~kg} \mathrm{H}_{2} \mathrm{SO}_{4} / \mathrm{t}$ has been consumed, which confirms the ANC determined using the ABA method (Table IV). However, as seen in Fig. 3, CS3 only maintains a pH above 4 until the equivalent of $20 \mathrm{~kg} \mathrm{H}_{2} \mathrm{SO}_{4} / \mathrm{t}$ has been consumed, suggesting that $67 \%$ of the ANC determined using the ABA method is readily available to neutralize acid. Thus the readily available or effective ANC of CS3 is considered to be $20 \mathrm{~kg} \mathrm{H}_{2} \mathrm{SO}_{4} / \mathrm{t}$ as it is considered to be of the utmost importance to maintain the $\mathrm{pH}$ of waste material above a $\mathrm{pH}$ of 4 to prevent an acidic leachate and oxidation of sulphide minerals via ferric iron [20].

SC4 neutralize $70 \mathrm{~kg} \mathrm{H}_{2} \mathrm{SO}_{4} / \mathrm{t}$ before the $\mathrm{pH}$ drops below a $\mathrm{pH}$ of 2.5 (Fig. 3), which is relatively close to the ANC determined by the ABA method (Table IV). However, CS4 consumes $60 \mathrm{~kg} \mathrm{H}_{2} \mathrm{SO}_{4} / \mathrm{t}$ before the solution reaches a pH of 4 . The readily available or effective ANC is thus considered to be $60 \mathrm{~kg} \mathrm{H}_{2} \mathrm{SO}_{4} / \mathrm{t}$ which is still relatively high when comparing it to the MPA (Table IV).

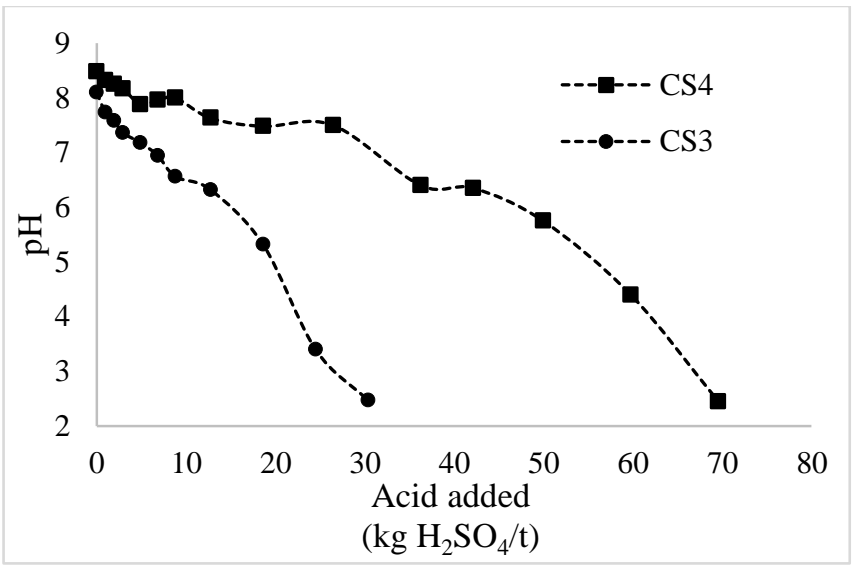

Fig. 3. ABCC plot of CS3 and CS4

\section{Net Acid Generation (NAG) results}

The NAG pH of CS1, CS2 and CS3 are below a pH of 4.5 (Table V). SC1, SC2 and CS3 are classified as PAF with a high acid generating capabilities according to the classification criteria summarized in Table II.

SC4 has a NAGpH of 5.3 and a NAG value of $0 \mathrm{~kg} \mathrm{H}_{2} \mathrm{SO}_{4} / \mathrm{t}$, CS4 is thus considered to be a NAF sample confirming ABA classification.

TABLE V:NAG RESULTS

\begin{tabular}{ccc}
\hline \multicolumn{3}{c}{ TABLE V:NAG RESULTS } \\
\hline Sample & NAGpH & $\begin{array}{c}\text { NAG } \\
\mathrm{kg} \mathrm{H}_{2} \mathrm{SO}_{4} / \mathrm{t}\end{array}$ \\
\hline CS1 & 1.5 & 116 \\
CS2 & 1.8 & 80 \\
CS3 & 1.9 & 45 \\
CS4 & 5.3 & 0 \\
\hline \hline
\end{tabular}

\section{CONCLUSION}

The results from the ABA, $\mathrm{ABCC}$ and NAG test indicate that samples CS1, CS2 and CS3 are potential acid forming samples. It can further be said that the waste rock tailings from which $\mathrm{SC} 1$ and SC2 have been collected have become acidic due to the low paste $\mathrm{pH}$ and are most likely generating an acidic leachate resulting in AMD that may be polluting water sources. Immediate action should be taken such as adding lime or limestone to the waste rock. Adding lime and limestone will increase the $\mathrm{pH}$ of the waste rock tailings resulting in the precipitation of heavy metals. However, adding lime and 
limestone will only be a temporary solution with its own limitations.

The acid generating capabilities of CS4 are considered to be NAF using the ABA, ABCC and NAG results. Using CS4 in the construction of a $\mathrm{CCBE}$ covers seems to be a feasible option to prevent the generation of AMD due to its low sulphide content and high acid neutralizing capabilities. However, this can only be confirmed by conducting leach column tests.

\section{ACKNOWLEDGMENT}

Author EFK acknowledged the financial support from the National Research Foundation (NRF) in South Africa (Grant No: 120323); Any opinion, findings and conclusions or recommendations expressed in this material are those of the authors and therefore the NRF does not accept any liability in regard thereto.

\section{REFERENCES}

[1] Dold, B., Basic concepts in environmental geochemistry of sulphide mine waste management, in: E.S. Kumar (Ed.), Waste Management, In Tech, Rijeka, 2010, Pp. 173-198 https://doi.org/10.5772/8458

[2] Koch, J., Chakraborty, S., Li, B., Kucera, J., Van Deventer, P., Daniell, A., Faul, C., Man, T., Pearson, D., Duda, B., Weindorf, C. and Weindorf, D. (2017). Proximal sensor analysis of mine tailings in South Africa: An exploratory study. Journal of Geochemical Exploration, 181, Pp.45-57. https://doi.org/10.1016/j.gexplo.2017.06.020

[3] Fosso-Kankeu E, Mulaba-Bafubiandi A, Mamba BB, Barnard TG. 2011. Assessing the effectiveness of a biological recovery of nickel from tailings dumps. Journal of Minerals Engineering. 24, Pp 470-472. https://doi.org/10.1016/j.mineng.2010.11.007

[4] Elvis Fosso-Kankeu, Alusani Manyatshe, Frans Waanders. 2017. Mobility potential of metals in acid mine drainage occurring in the Highveld area of Mpumalanga Province in South Africa: Implication of sediments and efflorescent crusts. International Biodeterioration and Biodegradation. 119, Pp.661-670. https://doi.org/10.1016/j.ibiod.2016.09.018

[5] E Fosso-Kankeu. 2018. Synthesized af-PFCl and GG-g-P(AN)/TEOS hydrogel composite used in hybridized technique applied for AMD treatment. Journal of Physics and Chemistry of the Earth. 105, Pp.170-176. https://doi.org/10.1016/j.pce.2018.02.015

[6] Sobek, A., Shuller, W., Freeman, J. and Smith, R. (1978). Field and laboratory methods applicable to overburdens and mine soils. 1st ed. Ihio: Industrial Environmental Research Laboratory, Office of Research and Development, U.S. Environmental Protection Agency, Pp.1-204.

[7] Smart, R., Skinner, B., levay, G., Gerson, A., Thomas, J., Schumann, H., Weisener, C. and Weber, P. (2002). ARD test handbook. 1st ed. Melbourne, Vic.: AMIRA International, Pp.1-42.

[8] Simate, G. and Ndlovu, S. (2014). Acid mine drainage: Challenges and opportunities. Journal of Environmental Chemical Engineering, 2(3), Pp.1785-1803.

https://doi.org/10.1016/j.jece.2014.07.021

[9] Skousen, J. (2017). A methodology for geologic testing for land disturbance: Acid-Base Accounting for surface mines. Geoderma, 308, Pp.302-311.

https://doi.org/10.1016/j.geoderma.2017.07.038

[10] Dold, B. (2017). Acid rock drainage prediction: A critical review. Journal of Geochemical Exploration, 172, Pp.120-132. https://doi.org/10.1016/j.gexplo.2016.09.014

[11] Stewart, W., Miller, S. and Smart, R. (2006). Advances in acid rock drainage (ard) characterisation of mine wastes. In: 7 th International Conference on Acid Rock Drainage (ICARD). LEXINGTON: America Society of Mining and Reclamation (ASMR), 2006(2), Pp.2098-2119. https://doi.org/10.21000/JASMR06022098

[12] Weber, P., Hughes, J., Conner, L., Lindsay, P. and Smart, R. (2006). Short-term acid rock drainage characteristics determined by paste ph and kinetic nag testing: cypress prospect, new zealand. In: 7th International
Conference on Acid Rock Drainage (ICARD). Lexington: American Society of Mining and Reclamation (ASMR), Pp.2289-2310. https://doi.org/10.21000/JASMR06022289

[13] Moodley, I., Sheridan, C., Kappelmeyer, U. and Akcil, A., 2018. Environmentally sustainable acid mine drainage remediation: Research developments with a focus on waste/by-products. Minerals Engineering, 126, Pp.207-220. https://doi.org/10.1016/j.mineng.2017.08.008

[14] Bussière, B., Benzaazoua, M., Aubertin, M. and Mbonimpa, M., 2004. A laboratory study of covers made of low-sulphide tailings to prevent acid mine drainage. Environmental Geology, 45(5), Pp.609-622. https://doi.org/10.1007/s00254-003-0919-6

[15] Karlsson, T., Räisänen, M., Lehtonen, M. and Alakangas, L. (2018). Comparison of static and mineralogical ARD prediction methods in the Nordic environment. Environmental Monitoring and Assessment, 190(719), Pp.1-29. https://doi.org/10.1007/s10661-018-7096-2

[16] Usher, B., Cruywangen, L., de Necker, E. and Hodgson, F. (2003). On-site and Laboratory Investigations of Spoil in Opencast Collieries and the Development of Acid-Base Accounting Procedures. Free State: Institute for Groundwater Studies University of the Free State, Pp.1-347.

[17] Bouzahzah, H., Benzaazoua, M., Plante, B. and Bussiere, B. (2015). A quantitative approach for the estimation of the "fizz rating" parameter in the acid-base accounting tests: A new adaptations of the Sobek test. Journal of Geochemical Exploration, 153, Pp.53-65. https://doi.org/10.1016/j.gexplo.2015.03.003

[18] Oh, C., Ji, S., Chon, C., Yim, G. and Cheong, Y. (2017). Reliability improvement for predicting acid-forming potential of rock samples using static tests. Environmental Monitoring and Assessment, 189(5), Pp.1-13. https://doi.org/10.1007/s10661-017-5906-6

[19] Nieva, N., Borgnino, L. and García, M. (2018). Long term metal release and acid generation in abandoned mine wastes containing metal-sulphides. Environmental Pollution, 242, Pp.264-276. https://doi.org/10.1016/j.envpol.2018.06.067

[20] E. Fosso-Kankeu, N. van Wyk, D. Moyakhe, F.B. Waanders, M. Le Roux, Q.P. Campbell. 2019. Acid-Base Accounting (ABA) of coal tailings from Middleburg area, South Africa. Editors: Elvis Fosso-Kankeu, Frans Waansders, Hemant Kumar Bulsara. $17^{\text {th }}$ Johannesburg International Conference on Science, Engineering, Technology and Waste Management (SETWM-19) Nov. 18-19, 2019 Johannesburg (South Africa). ISBN-978-81-943403-0-0. Vol. I. Pp 112-116. 